Original Research Paper

\title{
Biological Peculiarities of Archips rosana, the Insect Pest of the Sievers Apple Tree (Malus sieversii) in the Trans-Ili Alatau Ridge (the North Tien Shan)
}

\author{
${ }^{1 *}$ Gulzhanat Tanabekova, ${ }^{2}$ Roman Jashenko and ${ }^{3}$ Zhaozhi Lu \\ ${ }^{1}$ UNESCO Chair on Sustainable Development, Al-Farabi Kazakh National University, Almaty 050040, Kazakhstan \\ ${ }^{2}$ The Zoology Institute at the RK MES SC, Al-Farabi Kazakh National University, Almaty 050060, Kazakhstan \\ ${ }^{3}$ Xinjiang Institute of Ecology and Geography, Urumqi 830011, China
}

Article history

Received: 07-07-2020

Revised: 18-11-2020

Accepted: 21-11-2020

Corresponding Author:

Gulzhanat Tanabekova

UNESCO Chair on Sustainable

Development, Al-Farabi

Kazakh National University,

Almaty 050040, Kazakhstan

Email: tanabekova.guli@gmail.com

\begin{abstract}
The article provides new information on the phenology of a serious insect pest, the species of Archips rosana (Linnaeus, 1758) (Lepidoptera: Tortricidae), rendering fundamental harm to the Sievers apple trees, native to the Trans-Ili Alatau region (the North Tian Shan), which was not previously covered by studies. Material for research was obtained by the authors during two field seasons 2018-2019 by catching with an entomological net and making observations in nature at monitoring sites, as well as by growing all stages of development of the leafrollers in laboratory conditions of the Institute Zoology of Republic of Kazakhstan. The main objectives of the paper were set as follows: To establish the environmental factors behind the development stages of the A. rosana pest, to determine its phenological features and to identify the most vulnerable stage in its development in the given area. The paper describes in detail the study method and its outcome, workable in dealings against propagation of the pest and saving the indigenous Sievers apple tree. As a result, the most vulnerable stage convenient for combating the pest is the stage of the 1st 3rd instar larvae which appear in the Trans-Ili Alatau during the period from the second decade of April to the second decade of May.
\end{abstract}

Keywords: Archips rosana, Insect Pests, The North Tian-Shan, The Sievers Apple Tree, The Trans-Ili Alatau

\section{Introduction}

\section{Blue Colour is Correction for Manuscript}

To date, the largest massives of the wild Sievers apple tree populations in Central Asia were preserved in Kazakhstan. They are of great importance as a natural source of genetic material for maintaining the apple cultivars around the world (Cui et al., 2019). However, the area of wild populations of the apple tree species has significantly decreased over the past 100 years due to large scale clearance and land use in recent business activities (Dzhangaliev et al., 2003). At present, according to experts, the situation is close to critical, as the unique intraspecific diversity of the Kazakhstan populations of wild apple trees is currently being intensively reduced, leading to impoverishment of their gene pool value (Dzhangaliev, 2007; Volk et al., 2013). The same situation is applied to neighbouring areas of
China, Kyrgyzstan, Uzbekistan, Tajikistan and Turkmenistan. It is hard to restore these resources in a natural way, because, in fact, natural regeneration of the apple tree is absent in many of its local populations. In addition, wild populations of the fruit forests are in direct proximity to cultivated apple orchards which represent a serious problem (Zhang et al., 2014). The buffer protection zone along the natural populations is often not maintained (Panyushkina et al., 2017). Apart from alien plant species, there are threats to the wild fruit forests from insect pests and diseases of wild apple trees and of other wild fruit species (Jashenko and Tanabekova, 2019).

Currently, insect pests have become one of the main threats to wild populations of the sievers apple tree, causing enormous damage to the wild fruit forests in Kazakhstan (Kashcheev, 2010). It is important to note that the family of leafrollers (Tortricidae) of the Lepidoptera butterflies occupies a special place among 
other insect pests (Turekhanova and Tanabekova, 2018; Osipenko, 1983).

Leafrollers were given their name because the larvae of most of their species live in folded leaves, damaging and often skeletonising them. They pose a serious danger in entomocenoses of not only cultivated gardens and natural populations of fruit forests, but also in fruit and berry nurseries (Matesova, 1960; Zhigaltseva, 1963; Charmillot, 1992; Toropova et al., 2016; Knyazev and Dubatolov, 2019). Of particular danger to apple trees are larvae of the Archips rosana, which during the growing season causes an irreparable harm by damaging flower buds, lush leaves and fruits. The larvae of leafrollers cause tangible damage to young fruit trees, as they gnaw tops of green shoots during the crown formation.

A mass outbreak of the larvae can destroy the main part of yield, as they nearly eat away the inflorescences and pedicels of the first flowering ovaries. After eating the fruit tree bloom, the larvae attack leaves, thus disrupting the normal process of photosynthesis and settle within the young fruits, wasting the plant (Polat and Tozlu, 2010). This insect pest, if breaks out en mass, can affect $30 \%$ to over half of leaves of individual trees, reaching a threshold of harmfulness, significantly cutting down the quality and amount of yield.

The morphological and phonological features front wings of the $A$. rosana adult vary in colour from ochreyellow to gray and dark brown. Their hind wings are brownish-gray; females have bright orange-yellow pollination at the tip of wings. The wingspan is 15-22 $\mathrm{mm}$. Eggs are elongated, gray-green. A larvae has 18-20 $\mathrm{mm}$ long, translucent, of light green to dark olive-green colour. A pupa is 10-12 mm long, fusiform, yellowishbrown (Grichanov et al., 1994; Sukhotsky, 2009). Commonly eggs hibernate under tree barks, on smooth surface of tree branches (Smirnov and Ovsyannikova, 2012; Sukhotsky, 2009) and under the fallen leaves. The 1st and 2nd instar larvae gnaw buds, then passing on to flowers, destroy stamens, pistils and petals, skeletonise young leaves and squeeze them in a lump with own web thread. The 3rd-5th instar larvae damage the ovaries and fruits, gnawing holes in the pulp of an irregular shape, sometimes reaching the seed chamber or bones (Markelova, 1963; Klimczuk, 2005; Minyailo, 1990). Butterflies fly at dusk across the entire range Commonly A. rosana develops in one generation annually. Based their capacious as polyphagous insect, A. rosana was encountered on 130 species of 32 families host plants. Widely distributed, the species is known in Europe, the Mediterranean, Iran, Iraq, South Caucasus, Central Asia and Southern Siberia and was introduced to the Far East and North America (Markelova, 1963). The A. rosana causes significant harm to fruit and berry cultures (Gavrilov, 2009; AliNiazee, 1977; Knyazev and Dubatolov, 2019).
Successful resistance to $A$. rosana indispensably requires defining a vulnerable period in its development stages, during which trees could be treated against the pest with a maximum protection effect. To this end, timing of all development stages of the pest should be established including: (a) Beginning of the adult mass flight; (b) beginning of the egg laying en mass; and (c) beginning of the emergence of larva en mass.

\section{Materials and Methods}

\section{Study Area}

The studies were conducted in the area of Ili-Alatau State National Reserve, located in the surroundings of the Almaty megapolis, on the northern macroslope of the Trans-Ili Alatau ridge. The research material was obtained by the authors during the 2018-2019 field seasons by catchment of the species males and females of $A$. rosana with an entomological mesh and observations in-situ at natural monitoring sites. The growing the A. rosana sample throughout all stages of its development in the laboratory of the Zoology Institute (of the Science Committee at the Ministry of Education and Science of the Republic Kazakhstan - the RK MES SC) and their phenological observations in holding cages.

The studies were carried out at 3 monitoring sites of the Ili-Alatau State National Reserve as follows:

- The site no. 1, the Aksay branch, the Aksai forestry (elevation 1,345 m, N43ํ'23", E76 47'58")

- The site no. 2, the Talgar branch, the Saldatsai forestry (elevation $1,538 \mathrm{~m}, \mathrm{~N} 43^{\circ} 16^{\prime} 5^{\prime \prime}, \mathrm{E} 77^{\circ} 21^{\prime} 16$ )

- The site no. 3, the Issyk branch, the Issyk forestry (elevation 1,714 m, N43 15'11", E77²9'05")

\section{Leafrollers Sample Collection and Measurement}

During the field observations and material acquisition, the adult and larvae were collected in 0.5 liter glass containers, together with leaves of the Sievers apple tree, where the larvae resided. The leaves infected with the larva were also collected in individual laboratory tubes. The holding cages were numbered and the corresponding notes about place and time of collection, the plant, the nature of its damage and so on, were registered in a journal. Subsequently, the larvae were placed separately during their shedding and for maintenance.

In the laboratory, test-glasses with twisted leaves were covered with gauze and labeled. The larvae keeping and feeding were under the strict moisture control, required for normal development of the larvae. Therefore, containers with larvae were exposed to direct sun only for short time in order to prevent fogging up, as over-moistening and overheating would impact the larvae development. 
The adult of leafrollers were mounted on minuties and thin entomological pins; larvae and pupae were fixed by $70^{\circ}$ rectified spirit. The collected material is stored as part of the Entomology Laboratory collection of the Zoology Institute at the RK MES SC.

The studies were carried out with observation of the generally accepted entomological methods (Ruchin and Mikhailenko, 2018; Meshkova, 2009). Temperature was measured with a field thermometer; daily information on air temperature in the research area was obtained (Yandex, 2019). The phenological larva stages all of five ages were determined employing the techniques of measuring the head capsule (Polyakova and Gamayunova, 2013) as well as observations both in nature and in stationary holding cages. All entomological objects were examined with the KLM105 binocular microscope and were photographed.

\section{Results and Discussion}

The studies showed that the A. rosana hibernates in the Trans-Ili Alatau in the phase of egg, laid in a single layer on the smooth bark of the lower part of an apple tree trunk and in crutches of large branches, in clusters of about 60 pieces (40-100). Eggs laid in previous year develop under mountain conditions at an altitude of 1.200-1.600 m asl, in early April about two weeks, then the first instar larvae appear. In the first half of April, at the average daily air temperature of $+7-+14^{\circ} \mathrm{C}$ when the apple tree buds begin to swell, the sprout-up larvae feed together and then crawl out to top of the shoots. The 1st and 2nd instar larvae move closer to the swollen young buds and firstly damage buds and shoots, eating out round holes. Subsequently, the 2nd and 3rd instar larvae penetrate into flower-buds, where they destroy petals, pistils and stamens. Few days later, these larvae produce a thin web thread, with which they bound the leaves, forming a shelter (nest), where they continue feeding and developing (Fig. 1). Later on, the 3rd until 5th instar larvae damage ovaries and fruits, gnawing holes in the pulp of an irregular shape, sometimes deepening into seed chambers, resembling the damage caused by codling moth. Leaf bundles are a clear sign of the pest. When touching the larva, it will not fall, but hang in the air on a web thread.

Tables 1 and 2 provide data on the phenological features of $A$. rosana. The first appearance of larvae of this species in the Trans-Ili Alatau was fixed at the beginning of the second decade of April at an average daily air temperature of $+11^{\circ} \mathrm{C}$ and relative humidity of $56 \%$. Development of $A$. rosana larvae occurs here within 30-40 days. Its full development cycle includes four shedding and five stages.
The larvae continue feeding on apple trees until the end of May. According to our observations, pupation begins in the Trans-Ili Alatau at the beginning of the third decade of May; last time it was on May 23, 2019 at an average daily temperature of $+21^{\circ} \mathrm{C}$ (Fig. 2). At the end of May and in the beginning of June, the pupation turns massive. The pupae development process proper lasts for about two weeks at an average daily temperature of $+15-+25^{\circ} \mathrm{C}$ followed, from the second decade of June, by emergence of imago, which, upon flying out, proceed immediately to the mating and, further, the egg laying.

The first appearance of butterflies was recorded in mid June with the average daily temperature of +25 until $+30^{\circ} \mathrm{C}$ the mass flight occurred from the third decade of June onwards at an average daily temperature of $+28^{\circ} \mathrm{C}$. Females appear with a certain number of matured eggs. The egg laying begins 3-5 days after the flight of butterflies at the end of June at an average daily temperature of $+30^{\circ} \mathrm{C}$. One female individual lays about 400-800 eggs per season.

Egg maturation occurs throughout the entire period of the egg laying; it happens periodically at intervals of 2-4 days. The mass oviposition lasts 15-20 days starting from mid July. Eggs are laid on smooth parts of the bark. An egg clutch was observed to contain 55 eggs in average (from 13 to 146 eggs). The first clutches are the most numerous, then they reduce in number. Mainly observed in small clutches, non-viable eggs increase in number to the end of an imago life. Eggs in a clutch are of dark colour; they are laid in tree crutches, in crevices and cavities of the bark (Smirnov and Ovsyannikova, 2012). Clutches were observed to be laid also on leaves.

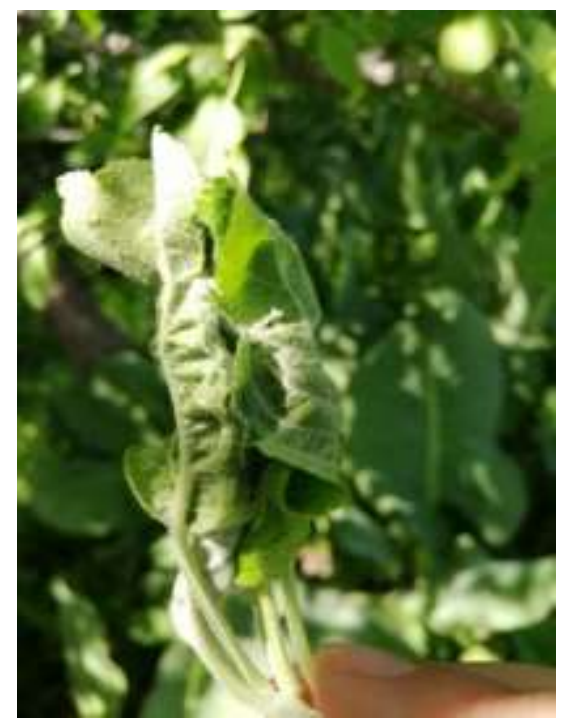

Fig. 1: A. rosana larvae in folds of the apple tree leaves (the site no. 1, the Aksai gorge) 

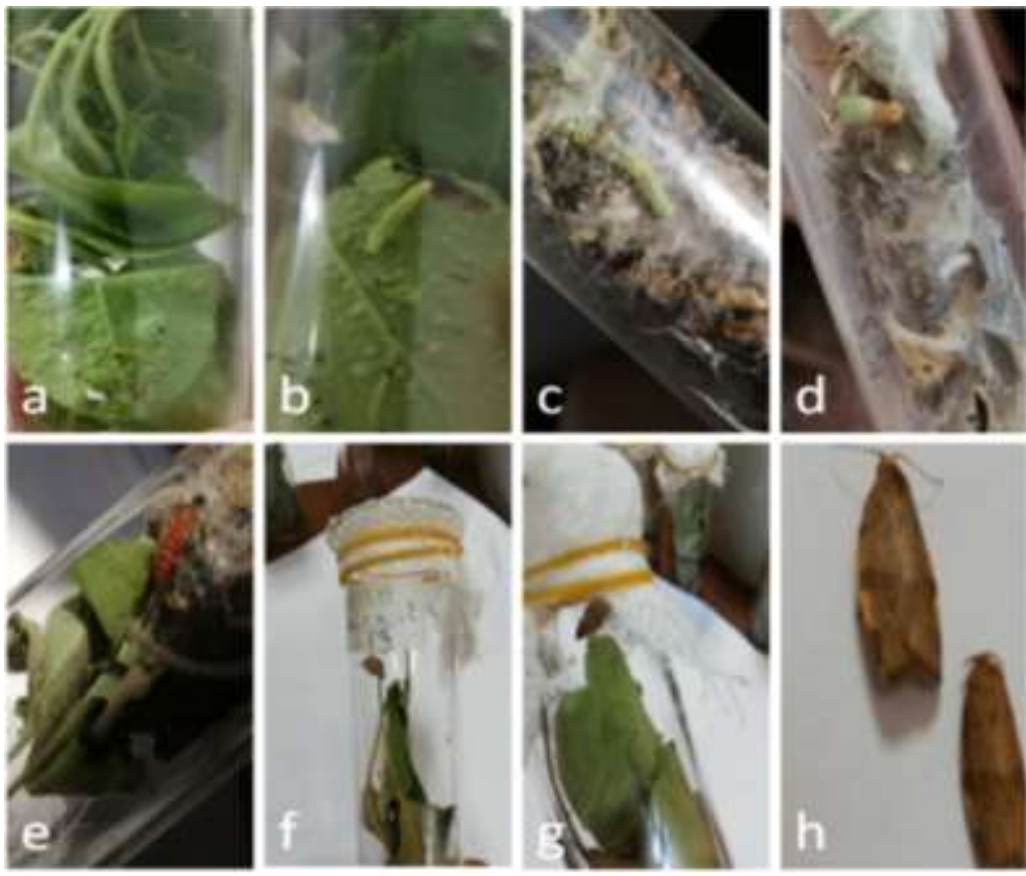

Fig. 2: Different stages of the development of the A. rosana obtained in the laboratory (a, b, c - larvae, d, e - pupae, f, g, h - imago) (Photos: G. Tanabekova)

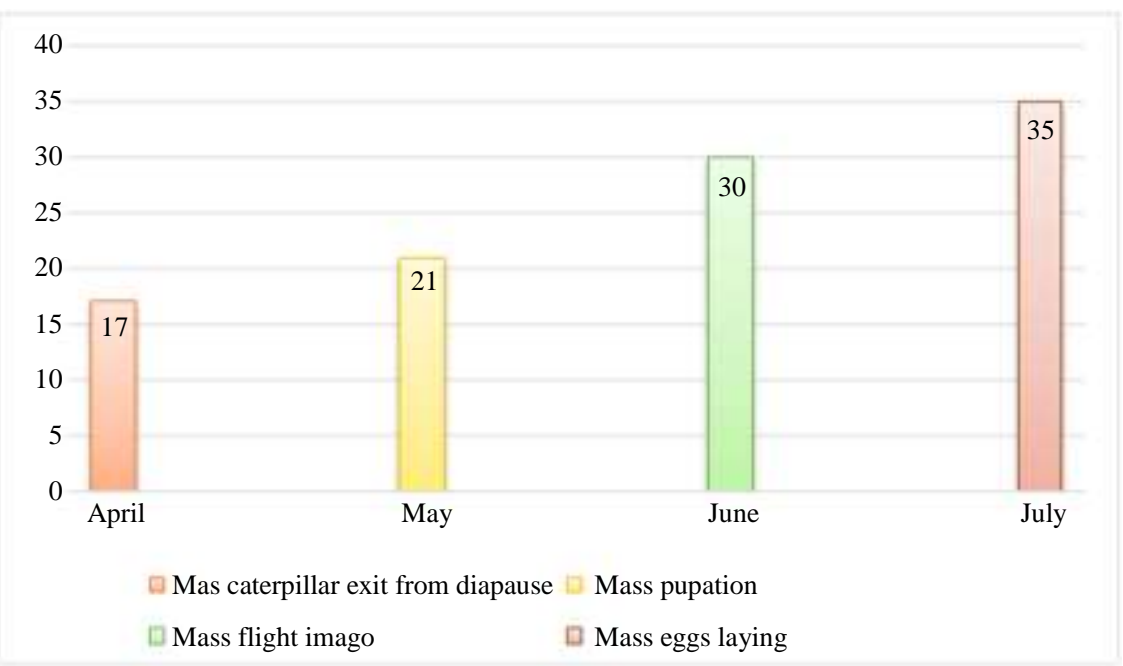

Fig. 3: Dependence of the phenology of A. rosana on temperature in the Trans-Ili Alatau in 2019

Table 1: Widths of head capsules in dependence of age and duration of the larva development stages

\begin{tabular}{llllll}
\hline Ages & I & II & III & IV & V \\
\hline Stage duration (days) & $9-12$ & $5-6$ & $5-6$ & $8-10$ & $5-7$ \\
Width of head capsule (mm) & $0.175-0.300$ & $0.325-0.450$ & $0.550-0.775$ & $0.850-1.275$ & $1.325-1.925$ \\
\hline
\end{tabular}

Table 2: The phenogram of the 2019 development of the A. rosana

\begin{tabular}{|c|c|c|c|c|c|c|c|c|c|c|c|c|c|c|}
\hline \multicolumn{3}{|c|}{ April } & \multicolumn{3}{|c|}{ May } & \multicolumn{3}{|c|}{ June } & \multicolumn{3}{|c|}{ July } & \multicolumn{3}{|c|}{ August } \\
\hline$\underline{I}$ & II & III & I & II & III & I & II & III & I & II & III & I & II & III \\
\hline 0 & $\begin{array}{l}\Omega \\
\Delta\end{array}$ & $\begin{array}{l}\Omega \\
\Delta\end{array}$ & $\begin{array}{l}\Omega \\
\boldsymbol{\Delta}\end{array}$ & $\begin{array}{l}\Omega \\
\Delta\end{array}$ & $\Omega \square$ & $\square$ & + & +0 & +0 & +0 & +0 & +0 & 0 & 0 \\
\hline
\end{tabular}

$\square$ - pupae; + - adult; 0 - egg laying; $\Omega$ - larvae; $\boldsymbol{\Delta}$ - the most vulnerable period 
Table 3: The A. rosana phenology in the Trans-Ili Alatau

\begin{tabular}{|c|c|c|c|}
\hline Development stages & Date and Year & $\begin{array}{l}\text { Night } \\
\text { temperatures }\left(\mathrm{T}^{\circ} \mathrm{C}\right)\end{array}$ & $\begin{array}{l}\text { Relative } \\
\text { humidity, (\%) }\end{array}$ \\
\hline Beginning of hatching the 1st instar larvae from overwintered eggs & 18 April 2019 & 17 & 52 \\
\hline Mass emergence of the 1 st instar larvae and the start of active feeding & 20-22 April 2019 & 12 & $46-47$ \\
\hline 2nd instar larvae & 01 May 2019 & 20 & 54 \\
\hline 3rd instar larvae & 06 May 2019 & 18 & 56 \\
\hline 4th instar larvae & 10 May 2019 & 26 & 55 \\
\hline 5th instar larvae & 17 May 2019 & 19 & 51 \\
\hline Beginning of pupation & 23 May 2019 & 21 & 52 \\
\hline Mass pupation & 27 May 2019 & 23 & 45 \\
\hline Beginning of the adult flight & 30 May 2019 & 30 & 51 \\
\hline Mass adult flight & 17 June 2019 & 28 & 48 \\
\hline Beginning of the egg laying & 23 June 2019 & 30 & 49 \\
\hline The mass egg laying & 08 July 2019 & 35 & 39 \\
\hline Beginning of diapause & 11 July 2019 & 33 & 39 \\
\hline
\end{tabular}

Table 2 indicates the most vulnerable stage, convenient to combat the pest. It is the stage of the 1st-3rd instar larvae that appear in the Trans-Ili Alatau starting from the second decade of April and continuing to the second decade of May. According to our observations, the mass flight of butterflies was often observed after raining. The A. rosana butterflies are active by night, flying out at dusk (when the air temperature is above $+15^{\circ} \mathrm{C}$ ) and hiding in shelters by day (on trunks, on branch sides under leaves). Table 3 was showed the data of the 2018-2019 phenological observations.

Duration of various development stages of $A$. rosana in the Trans-Ili Alatau as observed during 2018-2019 are as follows: The whole life cycle in 1 year (one generation); egg lives 9-10 months, the 1st-5th instar larvae 30-40 days; pupae 10-14 days; and adult living over 2 months.

Dependence of the phenology of $A$. rosana on temperature in the Trans-Ili Alatau in 2019 was presented in Fig. 3.

\section{Conclusion}

In the Trans-Ili Alatau, as in other parts of the range, the $A$. rosana develops one generation annually. The emergence of larvae from hibernation at middle altitudes begins at an average daily temperature of $+17^{\circ} \mathrm{C}$. The pupation stage lasts for about 10-14 days at an average temperature of $+21^{\circ} \mathrm{C}$. Mass pupation occurs in the $3 \mathrm{rd}$ decade of May at an average daily temperature of $+20-+25^{\circ} \mathrm{C}$. The adult appear from late May to early August with the mass flight in the second half of June at an average daily temperature of $+28^{\circ} \mathrm{C}$. Life of adult lasts 8 to 30 days. By early August, there is gradual decline of adult. The egg-laying begins in the third decade (June 26, 2019) at an average daily temperature of $+30^{\circ} \mathrm{C}$. The embryonic development of eggs includes three periods: Development to the diapause (differentiation and condensation of the germ line) lasting few days; the obligate diapause lasting over the summer, autumn and winter periods; and the final development that occurs in spring at $+8+13^{\circ} \mathrm{C}$, with the lower threshold for egg development $+8^{\circ} \mathrm{C}$. The egg development in nature ends in April.

The most vulnerable stage convenient for combating the pest is the stage of the 1st-3rd instar larvae which appear in the Trans-Ili Alatau during the period from the second decade of April to the second decade of May.

\section{Acknowledgment}

We thank reviewers for comments that greatly improved the manuscript.

\section{Author's Contributions}

All authors equally contributed in this work.

\section{Ethics}

Authors should address any ethical issues that may arise after the publication of this manuscript.

\section{References}

AliNiazee, M. T. (1977). Bionomics and life history of a filbert leafroller, Archips rosanus (Lepidoptera: Tortricidae). Annals of the Entomological society of America, 70(3), 391-401.

Charmillot, P. J. (1992). Progress and prospects for selective means of controlling tortricid pests of orchards. Acta phytopathologica et entomologica hungarica, 27(1-4), 165-176.

Cui, Z. J., Zhang, Y. L., Zhang, X., Luo, Z. H., Zhang, P., Golec, J., ... \& Lu, Z. Z. (2019). Life history and mortality factors of Agrilus mali Matsumura (Coleoptera: Buprestidae) in wild apples in Northwestern China. Agricultural and Forest Entomology, 21(3), 309-317. 
Dzhangaliev, A. D. (2007). Unique and global significance of the gene pool of apple forests in Kazakhstan. Report of the National Academy of Sciences. 5, 41-47.

Dzhangaliev, A. D., Salova, T. N., \& Turekhanova, P. M. (2003). The wild fruit and nut plants of Kazakhstan. HORTICULTURAL REVIEWSWESTPORT THEN NEW YORK-, 29, 305-372.

Gavrilov, I. A. (2009). Morphological variability and species borders in the genus Rhizopulvinaria (Homoptera: Coccinea). Zoosystematica Rossica, 18(2), 246-259.

Grichanov, I. Y., Bukzeyeva, O. N., \& Zakonnikova, K. V. (1994). The influence of temperature on the phenology of Archips rozana (Lepidoptera: Tortricidae). Archives of Phytopathology and Plant Protection, 29(2), 183-189.

Jashenko, R., \& Tanabekova, G. (2019, July). Insects that damage the wild populations of Malus sieversii in Kazakhstan. In IOP Conference Series: Earth and Environmental Science (Vol. 298, No. 1, p. 012018). IOP Publishing.

Kashcheev, V. A. (2010). Directory of insect pests of apple trees in wild-growing forests and gardens in Kazakhstan.

Klimczuk, P. (2005). The larval host plant of Polyommatus eroides (Frivaldszky, 1835)(Lycaenidae) from Poland with comments on the life history. Nota lepidopterologica, 28(2), 103.

Knyazev, S. A., \& Dubatolov, V. V. (2019). The leafrollers (Lepidoptera: Tortricidae) of Omsk Province, Russia. Acta Biologica Sibirica, 5(4), 96-108.

Markelova, E. (1963). Ecological features 01 the development of the rose leat roller Cacoec/a rosana L.(Lepidoptera, Tortricidae) in the orchards of the Moscow region. Ent. Obozr, 42(4), 730-735.

Matesova, G. Y. (1960). New species of soft scales from the family Coccidae (Homoptera, Coccoidea) in Kazakhstan. Trudy Instituta Zoologii Akademii Nauk Kazakhskoy SSR, 11, 196-204.

Meshkova, V. L. (2009). Seasonal development of foliage browsing insects. Novoe slovo, Kharkov.

Minyailo, V. A. (1990). On the assessment of survival and causes of death of eggs of the rose rosette Archips rosanus L. after wintering. Ecology. 5, 41-46.

Osipenko, T. I. (1983). The effect of damage to the leaves of apple trees with leaf-eating pests on the biochemical processes in them. Integrated Plant Protection from Pests and Crop Diseases. 1, 102-104.

Panyushkina, I. P., Mukhamadiev, N. S., Lynch, A. M., Ashikbaev, N. A., Arizpe, A. H., O'Connor, C. D., ... \& Sagitov, A. O. (2017). Wild apple growth and climate change in southeast Kazakhstan. Forests, $8(11), 406$.
Polat, A., \& Tozlu, G. (2010). Erzurum'da Archips rosana (Linnaeus, 1758)(Lepidoptera: Tortricidae)'nın kısa biyolojisi, konukçuları ve parazitoitleri üzerinde araştırmalar. Türkiye Entomoloji Dergisi, 34(4), 529-542.

Polyakova, L. V., Gamayunova, S. G., \& Jurova, P. T. (2013). Biochemical peculiarities of common oak old forest and 55-year old culture trees in connection with their suitability to an herbivorous insects. Фактори експериментальної еволюції організмів, 13, 92-96.

Ruchin, A. B., \& Mikhailenko, A. P. (2018). Fauna of mantids and orthopterans (Insecta: Mantodea, Orthoptera) of the Mordovia State Nature Reserve, Russia. Biodiversitas Journal of Biological Diversity, 19(4), 1194-1206.

Smirnov, S. N., \& Ovsyannikova, E. I. (2012). Dominant and potentially dangerous pests in nurseries of fruit and berry crops of the Leningrad Region. Plant Protection Bulletin. 1, 67-68.

Sukhotsky, M. I. (2009). Book of a Modern Gardener. Minsk: MFTSP.

Toropova, E. Y., Marmuleva, E. Y., Osintseva, L. A., Selyuk, M. P., \& Dyachenko, A. S. (2016). Spatiotemporal Distribution of Entomophages in Phytocenoses of Anthropogenically Modified Landscape in the Forest-steppe of Western Siberia. Biosciences Biotechnology Research Asia, 13(1), 257-271.

Turekhanova, R. M., \& Tanabekova, G. B. (2018). The most important insects are pests of the Sievers apple tree (Malus Sieversii) in Kazakhstan in the context of sustainable development. Eurasian journal of Ecology. 57 (4), 90-97.

Volk, G. M., Henk, A. D., Richards, C. M., Forsline, P. L., \& Chao, C. T. (2013). Malus sieversii: A diverse Central Asian apple species in the USDA-ARS national plant germplasm system. HortScience, 48(12), 1440-1444.

Zhigaltseva, M. I. (1963). Forecast of the number of leaflets in the forests and gardens of Moldova. Issues of forest protection. 2, 30-33.

Zhang, T., Yuan, Y., He, Q., Wei, W., Diushen, M., Shang, H., \& Zhang, R. (2014). Development of tree-ring width chronologies and tree-growth response to climate in the mountains surrounding the Issyk-Kul Lake, Central Asia. Dendrochronologia, 32(3), 230-236.

Yandex. (2019). Yandex weather. https://yandex.kz/pogoda/almaty. 